\title{
Secondary Movements: Improving Compliance and Building Trust among the Member States?
}

\section{Daniel Thym"}

Trust is an essential prerequisite for a functioning area of freedom, security, and justice. In a foundational judgment, the Court of Justice stated paradigmatically: 'At issue here is the raison d'être of the European Union and the creation of..., in particular, the Common European Asylum System, based on mutual confidence.' ${ }^{1}$ Our theme is not the controversial case law on fundamental rights limits to Dublin transfers, judges dealt with when emphasising the relevance of mutual trust, but the more generic question about legal rules concerning asylum seekers taking advantage of the border-free Schengen area to relocate themselves autonomously. The phenomenon is usually referred to as 'secondary movements', even though the Commission evaded the term in the 'Pact'. Nevertheless, it referred to the issue indirectly, in the title of the accompanying press release with its call for a 'balance between responsibility and solidarity'.

When it comes to policy debates among Member States, responsibility and solidarity are two sides of the same coin. The formula indicates the ambition to accommodate divergent preferences of countries at the external borders and elsewhere. ${ }^{3}$ Search for 'responsibility and solidarity' has become a catchphrase for the relocation of asylum seekers and other measures in support of 'frontline' Member States (solidarity), as well as for the effective implementation of asylum laws throughout the European Union, including measures preventing or sanctioning secondary movements (responsibility). The formula takes up basic principles of primary law for mutual assistance (Article 80 TFEU) and loyal application of Union law

* Professor of Public, European and International Law and managing Director of the Research Centre Immigration \& Asylum Law at the University of Konstanz, Germany.

1 ECJ, N.S. and others, C-411/10 \& C-493/10, EU:C:2011:865, para 83.

2 Commission, 'A Fresh Start on Migration' (Press Release IP/20/1706, 23 September 2020) <https://ec.europa.eu/commission/presscorner/detail/en/ip_20_1706> accessed 15 December 2021.

3 See the introductory chapter by Daniel Thym, in section 2. 
(Article 4(3) TEU). ${ }^{4}$ It is attractive for signalling the desire for a political compromise, notwithstanding profound cleavages on the substance.

\section{EU Asylum Reform: Two Competing Narratives}

In the debate about EU asylum policy, we are confronted with two competing narratives which underlie the breakdown of mutual trust among 'Southern' and 'Northern' states: While countries at the external border regularly complain about having to shoulder the 'burden' without adequate solidarity, politicians further north often decry the alleged incapacity of peers in running functioning asylum systems and in preventing onward movements. The first narrative is fed by the well-known pictures of arrivals at the external borders. When it comes to the second narrative, German, Austrian, Swedish, or Dutch politicians, amongst others, will highlight the everyday experience of state authorities with asylum seekers and beneficiaries of international protection submitting another application, after having been registered in the Eurodac database, or after having received a protection status, previously in countries such as Italy, Greece, or Spain.

Statistics about secondary movements are notoriously unreliable, but the high number of take back requests under the Dublin system and discrepancies between the numbers of asylum applications and administrative first instance decisions in Italy or Greece are indicators of the lived experience of secondary movements. ${ }^{5}$ During the first nine months of 2021, German authorities made more than 30 thousand take back requests to other Member States under the Dublin III Regulation, mostly following a 'hit' in the Eurodac database, even though there were comparatively few new arrivals in 'frontline' Member States at the time. ${ }^{6}$ They estimate that more than 30,000 beneficiaries of international protection, which

4 See further Editorial Comments, 'From Eurocrisis to Asylum and Migration Crisis: Some Legal and Institutional Considerations about the EU's Current Struggles' (2015) 52 CML Rev. 1437, 1442-1444; and Iris Goldner Lang, 'The EU Financial and Migration Crises: Two Crises - Many Facets of EU Solidarity' in Andrea Biondi, Eglé Dagilyté and Esin Küçük (eds), Solidarity in EU Law (Elgar 2018) 133-160.

5 See Markus Wagner, Jimy Perumadan and Paul Baumgartner, 'Secondary Movements' (CEASEVAL Research on the Common European Asylum System No 34, 2019) 5-7.

6 On constantly updated statistics, see for Germany 'Aktuelle Zahlen' <www.bamf .de/DE/Themen/Statistik/Asylzahlen/asylzahlen-node.html>; and for Eurostat 
are not covered by the take back procedure under the Dublin system at present, moved to Germany from Greece during the same period. ${ }^{7}$ A substantial number of people who had arrived in previous years were moving northwards: some comparatively quickly, others after months or years of residence. While most onward movements had traditionally taken place before an administrative first instance decision in the country of first arrival, recent years have witnessed increasing number of beneficiaries of international protection moving northwards on the basis of their protection status.

Against this background, this contribution discusses those elements of the Commission proposals on asylum policy reform which address the phenomenon of secondary movements, including the recent - and surprising - initiative to facilitate refusal of entry at internal Schengen borders presented in December 2021. In doing so, it complements the discussion of solidarity measures in the contribution by Francesco Maiani. While both aspects cannot be disentangled politically, in line with the 'solidarity and responsibility' formula, it can be beneficial to address secondary movements separately from an analytical perspective. To do so sheds light on one aspect of the legislative negotiations which rarely receives much academic attention, although it is highly relevant for the policy debate. Special attention will be paid to interdisciplinary analyses about the driving forces behind secondary movements, which allow us to indicate the practical impact of different reform options that have been put forward.

\section{Driving Forces behind Secondary Movements}

A political compromise among the Member States, and among the EU institutions, is the main hurdle for any reform of asylum policy. Without it, no new legislation will be adopted. Nevertheless, the focus of much of the political negotiations on finding a common ground among the political actors should not detract us from another challenge: can the proposals function reasonably well in practice? Indeed, experiences with the notorious ineffectiveness of the take back procedure (most transfer decisions under the Dublin system are not realised in practice) and the lacklustre

$<$ https://ec.europa.eu/eurostat/databrowser/view/migr_asyappctza $>$, both accessed 15 December 2021.

7 See Manuel Bewarder and Carolina Drüten, 'Freifahrtschein nach Deutschland' (Die Welt, 15 December 2021) 6. 
implementation of the Relocation Decisions adopted in 2015 indicate that changing the laws may not be enough. ${ }^{8}$ Member States and individuals might simply not comply with statutory obligations promulgated in the EU's Official Journal. Major discrepancies between the law in the books and the law in practice are a major challenge of any reform of the Dublin system, for solidarity and responsibility alike. ${ }^{9}$

Social scientists teach us that it can be notoriously difficult to identify the reasons why people leave their home states, how they choose destination countries, and in what respect these preferences may change over time. Multiple 'push' and 'pull' factors overlap and their relative weight depends on the circumstances, with social and ethnic networks and the infrastructure (including 'smugglers') influencing the overall outcome. ${ }^{10}$ Research specifically on onward movements of asylum seekers is rare and notoriously context-dependent, making it difficult to draw abstract conclusions about the relative weight of various driving forces. ${ }^{11}$ When it comes to secondary movements, the choice of destination country may vary over time, for instance when individuals stay in a first state for several months or years before moving on to a second state, thus turning the initial destination into a 'transit country' (either because they had always intended to do so, or after changing their minds). An assessment is complicated by the comparatively low level of information on the part of many asylum seekers, which ethnographic research has unveiled, thus rendering symbols, stories, and perceptions as relevant as 'hard' facts. ${ }^{12}$

8 On take back decisions, see Francesco Maiani and Vigdis Vevstad, 'Setting up a Common European Asylum System' (Study for the European Parliament PE 425.622, August 2010) 157-162; and on relocation, see Commission, 'Progress Report on the Implementation of the European Agenda on Migration' COM(2018) 250 of 14 March 2018, 16, Annex 4.

9 See generally Francesco Maiani, 'Responsibility Allocation and Solidarity' in Philippe De Bruycker, Marie De Somer and Jean-Louis De Brouwer (eds), From Tampere 20 to Tampere 2.0. Towards a new European consensus on migration (EPC 2019) 103-118.

10 For an instructive overview, see Hein de Haas, Stephen Castles and Mark J. Miller, The Age of Migration: International Population Movements in the Modern World (6th edn, Palgrave 2020) ch 3.

11 See generally Valeria Ottonelli and Tiziana Torresi, 'When is Migration Voluntary?' (2013) 47 IM Rev. 783-813; Wagner, Perumadan and Baumgartner, 'Secondary Movements' (n 5) 11-16; and (Dutch) Advisory Committee on Migration Affairs (ACVZ), 'Secondary Movements of Asylum Seekers in the EU' (November 2019).

12 See Joris Schapendonk, 'Turbulent Trajectories. African Migrants on Their Way to the European Union' (2012) 2 Societies 27-41; and Jasper D. Tjaden and Tobias 
Notwithstanding these uncertainties, common features define the social scientific analysis. Refugees and migrants generally have a low level of knowledge about the specificities of asylum laws, let alone the intricacies of supranational legislation. Statutory details of domestic or supranational asylum legislation, which define the policy debate, will influence decisionmaking to a limited extent only. Individuals will not always have heard about the Dublin system before reaching European soil, nor will they usually have an understanding of the procedural subtlety of the take back procedure or legal remedies. ${ }^{13}$ Social benefits can be a factor amongst others, even though migrants will rarely distinguish between social benefits sensu stricto and the general quality of public services, including education or healthcare. ${ }^{14} \mathrm{Few}$ people leave home states with the intention to benefit from the welfare state, but inappropriate reception conditions in countries of first arrival can influence onward movements later.

Having said this, other elements than the contours of asylum legislation and the welfare state are, on the whole, probably more important. Fortunately, all Member States guarantee physical safety as a matter of principle (it is a crucial factor influencing forced migration otherwise). However, economic prospect and labour market success, real or perceived, can vary significantly between the Member States, as do living conditions. These elements are undoubtedly core factors. ${ }^{15}$ Moreover, ethnic and family networks are generally a core factor determining where people want to

Heldland, 'Does Welcoming Refugees Attract more Migrants? The Myth of the "Merkel Effect"' (Kiel Working Paper No 219, August 2021).

13 See Heaven Crawley and Jessica Hagen-Zanker, 'Deciding Where to Go: Policies, People and Perceptions Shaping Destination Preferences' (2019) 57 International Migration 20, 22-30; and Eiko R. Thielemann, 'How Effective are National and EU Policies in the Area of Forced Migration?' (2012) 31 Refugee Survey Quarterly 21, 25-28.

14 See Ole Agersnap, Amalie Sofie Jensen and Henrik Kleven, 'The Welfare Magnet Hypothesis: Evidence from an Immigrant Welfare Scheme in Denmark' (NBER Working Paper No 26454, November 2019) <www.nber.org/papers/w26454> accessed 15 December 2021; and generally Petra W. de Jong and Helga A.G. de Valk, 'Intra-European Migration Decisions and Welfare Systems: The Missing Life Course Link' (2020) 46 Journal of Ethnic and Migration Studies 1773, 171-176.

15 See Eric Neumayer, 'Asylum Destination Choice: What Makes some European Countries more Attractive than Others?' (2004) 5 European Union Politics 155-180; and Katie Kuschminder, 'Deciding which Road to Take' (2019) Migration Policy Institute Issue Brief No 10. 
go. ${ }^{16}$ The length of procedures can also influence decisions; the longer procedures last, the more likely individuals will have taken roots in a country and are less likely to comply with an obligation to leave the country, or to support or tolerate state measures in this respect. ${ }^{17}$ Thus, the administrative inefficiency of the take back procedure is one element amongst others, even though the abovementioned factors are certainly more relevant in terms of influencing decisions whether to leave and where to go.

\section{Implications for the Reform Debate}

An essential lesson from the driving forces behind secondary movements is that EU institutions should strive for a smart legislative design in order to optimise compliance. Note that this is not a normative claim to respect the preferences of asylum seekers as a matter of justice (even though some may want to argue that), but a matter of regulatory self-interest. An asylum system which optimises compliance works better in practice, and the European Union desperately needs a better functioning regime given the dismal performance of the Dublin system.

Ideally, the policy debate will draw at least three inter-related conclusions from the inspection of the driving forces and practical experiences with the Dublin system. Firstly, the absence of systematic border controls within the Schengen area contrasts with the idea behind coercion-based transfers whose failure obliges host states to assume jurisdiction on behalf of the country that would normally be responsible. Secondly, there are administrative and practical limits to relocating, or transferring, tens of thousands of applicants among the Member States, which has been pejoratively dubbed an exercise in 'technocratic overreach'18. Thirdly, labour market prospect and living conditions, as well as ethnic and family networks, are at least as important as the nitty-gritty of asylum legislation in terms of influencing secondary movements.

16 See Thomas Faist, The Volume and Dynamics of International Migration and Transnational Spaces (Clarendon 2000); and Paul Collier, Exodus: How Migration is Changing Our World (OUP 2013) ch 2.

17 See Simone Bertoli, Herbert Brücker and Jesús Fernández-Huertas Moragac, 'The European Crisis and Migration to Germany' (2016) 60 Regional Science and Urban Economics 61-72; and the ethnographic study by Antje Ellermann, States against Migrants: Deportation in Germany and the US (CUP 2009).

18 Luuk van Middelaar, Alarums and Excursions: Improvising Politics on the European Stage (Agenda 2019) 100. 
From the point of view of the interdisciplinary rational choice theory, decisions can be influenced by means of either positive incentives or negative sanctions: the proverbial 'carrots and sticks'. Unfortunately, policy debates about secondary movements are often framed in a binary manner. While NGOs plead for positive incentives, states concentrate on sanctions. Such either/or-logic is a false dichotomy, as positive and negative incentives can be combined. Doing so will not only improve compliance (which is in the interest of everyone); it may even facilitate political agreement if different positions coalesce, also among the EU institutions. We shall come back to these considerations in our comments on family life.

Moreover, EU institutions should strive to improve statistics. Secondary movements are an excellent example to illustrate the deficits of contemporary asylum statistics. A core deficit concerns the focus on the number of asylum applications, not persons. That can inflate numbers as a result of double counting, whenever someone applies for asylum several times. Furthermore, there is no reasonably reliable information about how many individuals are residing in a country at any point in time. The number of asylum applications in Greece, for instance, usually includes those who have moved elsewhere. That is why the Commission put forward proposals to expand Eurodac. They consist of two lawyers, which have to be read jointly: the original Proposal of 2016; and an amendment introducing additional elements as an integral part of the Pact in $2020 .{ }^{19}$ Eurodac is to become a genuine migration and asylum database, allowing Member States to track individuals (instead of counting applications) and facilitating the identification of the state responsible. Of course, migration statistics will never be perfect, since authorities will never track all people reliably, but better data can help to rationalise the debate nonetheless.

\section{Family Life: Recognising an Essential Motivation}

An essential bone of contention in political debates about Dublin reform is the definition of 'family member', which, at present, comprises spouses and minor children. ${ }^{20}$ This somewhat narrow definition reflects social

19 See Commission, Proposal for a Regulation on Eurodac, $\operatorname{COM}(2016) 272$ of 4 May 2016; and the Amended Proposal for a Regulation on Eurodac, COM(2020) 614 of 23 September 2020.

20 See Article 2(g) Dublin III Regulation (EU) No 604/2013; in line with the original Article 4(2) Convention Determining the State Responsible for Examining Applications for Asylum Lodged in one of the Member States of the European Com- 
practices in contemporary Europe and largely corresponds to human rights law. ${ }^{21}$ Nevertheless, it constitutes a bottleneck for the practical relevance of the criteria supporting family unity in Articles 9-11 Dublin III Regulation (EU) No 604/2013. For decades, frontline states and NGOs have called for a broader definition embracing other relatives, in particular siblings, thus obliging countries further North to actively take charge of applicants arriving in Greece or Italy whose relatives are residing elsewhere. Such an amendment was proposed by the Commission in 2016 and, again, 2020; it was rejected in the Council on the first occasion, while discussions on the latest proposal are ongoing. ${ }^{22}$ While the Rapporteur's Draft Report for the EP's LIBE Committee proposes to abandon the generous definition, the Council Presidency's compromise proposals of 2021 maintained the idea, which many governments reject nevertheless. ${ }^{23}$

The consequences of such a potential change are obvious: countries with a residual population of refugees would have to assume responsibility for the asylum applications of siblings and other family members covered by the extended definition. They would have to be flown to countries like Germany or Sweden, irrespective of whether their application has a realistic chance of being successful. As an intermediary jurisdictional test, the Dublin procedure does not pre-empt the outcome of the assessment of the admissibility or merits of the asylum application in the state responsible. ${ }^{24}$ It would potentially cover those subject to asylum border procedures, since Member States may, on their own initiative, verify whether other countries hold jurisdiction during border procedures. ${ }^{25}$ An extended definition of

munities (adopted 15 June 1990, entered into force 1 September 1997) [1997] OJ C254/1; and ECJ, État belge, C-194/19, EU:C:2021:270, para 30.

21 See ECtHR, judgment of 9 October 2003 [GC], No. 48321/99, Slivenko et al. v. Latvia, para 94, including careful extension to other relatives in situations of dependency in line with Article 16(1) Dublin III Regulation (EU) No 604/2013, as interpreted by ECJ, K, C-245/11, EU:C:2012:685, paras 46-53.

22 See Article 2(g) Commission Proposal for an Asylum and Migration Management Regulation, $\operatorname{COM}(2020) 610$ of 23 September 2020 (hereafter 'AMMR Regulation'); Article 2(g) Commission Proposal for a Dublin III Regulation, $\operatorname{COM}(2008) 820$ of 3 December 2008; and the Presidency's compromise proposals in Council doc. 8895/18 of 17 May 2018, 26-27.

23 See EP Draft Report on the Proposal for an Asylum and Migration Management Regulation (Rapporteur: Tomas Tobé), PE698.950v01-00 of 11 October 2021, Amendment 32; as well as Council doc. 10450/21 of 10 June 2021; and Council doc. 11617/21 of 9 July 2021.

24 See Article 20(1) Dublin III Regulation (EU) No 604/2013; Article 33(1) Asylum Procedures Directive 2013/32/EU; and ECJ, Mirza, C-695/15 PPU, EU:C:2016:188.

25 See Article 41(7) Proposal for an AMMR Regulation (n 22). 
family member would effectively legalise what social scientists call—somewhat pejoratively-'chain migration'26 along family networks.

In sum, the scope of jurisdiction for family members is essential. Firstly, it concerns comparatively large numbers of people (unlike amendments concerning jurisdiction based on previous stays or studies ${ }^{27}$ ). Defining 'family life' is, in other words, a critical element of the policy debate. Secondly, an extended definition would recognise that family networks are one of the most relevant - and ethically most compelling-drivers of secondary movements. Instead of trying to counter movements that are most difficult to prevent or sanction in practice, those critical of secondary movements may recognise the inevitable and invest scarce resources in improving other elements of the Dublin system. Thirdly, opposition by the main asylum destination countries could possibly be mitigated in the negotiations. By way of example, responsibility for siblings could be counted towards the solidarity quota; ${ }^{28}$ or it might be accepted politically in return for other changes, for instance stable asylum jurisdiction.

\section{5. 'Other Carrots': Incentivising Compliance}

While an extended definition of 'family member' arguably constitutes the single most relevant incentive, the Commission adds further novelties. When relocating asylum seekers under the solidarity mechanism, discussed at length by Francesco Maiani in his contribution to this volume, Member States 'shall' take into account 'meaningful links' when determining which people to relocate. ${ }^{29}$ The Commission refrains from defining the notion of 'meaningful link'. However, it may be conceived in line with the EP's position on the erstwhile Proposal for a Dublin IV Regulation, which had sponsored the relocation of asylum seekers on the basis in particular [of] family, cultural or social ties, language skills or other meaningful

26 John S. MacDonald and Leatrice D. MacDonald, 'Chain Migration, Ethnic Neighborhood Formation and Social Networks' (1964) 42 Milbank Memorial Fund Quarterly 82-97.

27 Cf Articles 19(4), 20 Proposal for an AMMR Regulation (n 22).

28 Similarly, with regard to the flexibility clause in today's Article 17 Dublin III Regulation, the EP's LIBE Committee Draft Report (n 23) Amendment 108.

29 See Articles 57(3)(1), 49(2) Proposal for an AMMR Regulation (n 22). 
links which would facilitate his or her integration into that other Member State.' 30

We should recognise that the practical relevance of the 'meaningful link' criterion would depend on whether the legislature extended the definition of 'family member' and broadened jurisdiction on the basis of previous stays or studies. If that happened, siblings and former students would be transferred elsewhere on the basis of the hierarchy of substantive criteria for asylum jurisdiction, which take priority over solidarity-based relocation..$^{31}$ In this case, the 'meaningful link' criterion could be used, by way of example, for language skills or, controversially, religious affiliation. Note that neither the Commission's Proposal of 2020 nor the EP's Report of 2017 foresee an individual right to be transferred elsewhere on the basis of 'meaningful links'; Member States are entrusted to take that aspect into account. ${ }^{32}$ To recognise meaningful links would certainly not prevent secondary movements in itself, but it may be another element fostering compliance and improving the legitimacy of the overall system.

Legal onward movements after the completion of the asylum procedure may similarly be considered. NGOs had called for such 'free choice' for years, albeit to little avail. ${ }^{33}$ The Commission does not support the idea, ${ }^{34}$ although it makes a small but symbolically important move in its direction in the Pact presented in September 2020. Beneficiaries of international protection with long-term residence status are to benefit from intra-European mobility after 3 instead of the regular 5 years, which the Long-Term Residents Directive usually requires for status acquisition. ${ }^{35}$ According to existing rules, the three-year period would be calculated from the date

30 Article 24b read in conjunction with Article 19(2) EP LIBE Committee, Report on the Proposal for a Dublin IV Regulation, PE 599.751v03-00 of 6 November 2017.

31 See Article 57(3) Proposal for an AMMR Regulation (n 22).

32 See generally Francesco Maiani, 'The Reform of the Dublin System and the Dystopia of "Sharing People" (2017) 24 Maastricht Journal of European and Comparative Law 622, 634-640.

33 By way of example, see the policy paper of various German associations, 'Memorandum Flüchtlingsaufnahme in der Europäischen Union: Für ein gerechtes und solidarisches System der Verantwortlichkeit' (March 2013) 20-22<www.proasyl.d e/wp-content/uploads/2015/09/Memorandum_Dublin_deutsch.pdf $>$ accessed 15 December 2021.

34 See also Commission, 'Communication: Towards a Reform of the Common European Asylum System and Enhancing Legal Avenues to Europe' COM(2016) 197 of 6 April 2016, 7-9.

35 See Article 71 Proposal for an AMMR Regulation (n 22). 
of the asylum application, even though half of the Member States use the statutory option of counting only half of that period. ${ }^{36}$ Irrespective of the calculation of the period of previous residence, practical effects of the amendment would probably be limited. Long-term residence status presupposes economical self-sufficiency, thus excluding those who receive social benefits. ${ }^{37}$ Moreover, destination countries retain the authority to refuse mobility on the basis of, amongst others, labour market tests. ${ }^{38}$

Theoretically, the Council and the European Parliament could broaden opportunities for legal onward movement for economic purposes during the legislative process. Thus, the legislature could follow the model of the revised Blue Card Directive (EU) 2021/1883 and extend other labour migration instruments to beneficiaries of international protection. ${ }^{39} \mathrm{Hy}-$ pothetically, the institutions could even introduce new rules on labour mobility specifically for refugees. Doing so would not result in unfettered 'free choice' and could be subject to predefined criteria, such as a work contract and economic self-sufficiency. ${ }^{40}$ Free movement of Union citizens presents a far-reaching model, although institutions are free to agree on intermediate solutions with less rights for third country nationals. ${ }^{41}$ Such an outcome appears unlikely politically, but the idea of enhancing legal mobility may serve as a point of reference in policy debates nonetheless.

36 See Article 4(2), (3) Long-Term Residents Directive 2013/32/EU, as amended by Directive 2011/51/EU amending Council Directive 2003/109/EC to extend its scope to beneficiaries of international protection [2011] OJ L32/1; and Commission, 'Report on the implementation of Directive 2003/109/EC' COM(2019) 161 of 29 March 2019, 3.

37 Ibid Article 5(1)(a).

38 Ibid Articles 14-17.

39 See Article 3(1), (2)(a), (b) Blue Card Directive (EU) 2021/1883; by contrast, asylum seekers and beneficiaries of international protection are excluded from Article 2(2)(a) Students and Researchers Directive (EU) 2016/801; as well as Article 2(1) ICT Directive 2014/66/EU and Article 2(3) Seasonal Workers Directive 2014/36/EU, which require residence abroad and do not, therefore, cover those living on the territory already.

40 For different options, see German Expert Council on Integration and Migration (Sachverständigenrat für Integration und Migration), Chancen in der Krise: Zur Zukunft der Flüchtlingspolitik in Deutschland und Europa, Jahresgutachten 2017, 41-45 <www.svr-migration.de/wp-content/uploads/2017/10/SVR_Jahres gutachten_2017.pdf $>$ accessed 15 December 2021; the author of this chapter serves as the Council's vice chairperson.

41 Article 45 TFEU and Articles 45(1), 52(2) CFR do not cover third country nationals. 


\section{Streamlined Procedures}

At present, the Dublin system often results in lengthy and ineffective take back procedures, which, moreover, often fail in practice. German statistics show that the initial designation of asylum jurisdiction by state authorities usually takes several months, followed by another two months during which domestic courts decide on whether to reinstall the suspensive effects of appeals. Thus, asylum seekers are legally obliged to return to the state responsible only after up to one year after having first entered. ${ }^{42}$ Such long procedures are a problem in their own right, considering that extended periods of factual residence render it less likely that asylum seekers will voluntarily respect the take back decision, or tolerate enforcement measures. Procedural inefficiency turns secondary movements into a self-fulfilling prophecy, culminating in the transfer of jurisdiction.

Against this background, it is apparent why the Commission proposes to streamline procedures: the take back procedure shall be turned into a simple notification subject to shorter time limits; the scope ratione personae is extended to beneficiaries of international protection and those who had been relocated; and legal remedies are to be considerably curtailed, requiring domestic courts to decide on the suspensive effect within one month. ${ }^{43}$ In future, only those challenging the transfer decision on grounds of family links or the real risk of inhumane or degrading treatment are to be given a legal remedy, thus going even beyond the Proposal of $2016 .{ }^{44}$

Restricting legal remedies returns to the status quo ante under the former Dublin II Regulation, which had similarly provided for legal remedies with suspensive effects under restrictive conditions only. ${ }^{45}$ It seems to me that the Court of Justice would probably accept the amendment, given that the case law extending legal remedies was based on the wording and general scheme of the Dublin III Regulation. ${ }^{46}$ If the latter is reversed, the

42 See the latest data on the year before the COVID-19 pandemic, which resulted in considerable additional delays, in Federal Government (Bundesregierung), 'Antwort auf die Kleine Anfrage der Fraktion Die Linke: Ergänzende Informationen zur Asylstatistik für das Jahr 2019' (Bundestag-Drucksachen 19/18498, 2 April 2020) 48 <https://dserver.bundestag.de/btd/19/184/1918498.pdf > accessed 15 December 2021.

43 See Articles 26(1)(c), (d), 31, 33(1) Proposal for an AMMR Regulation (n 22).

44 Ibid Article 33(3)(1); in line with Article 28(4), (5) Commission Proposal for a Dublin IV Regulation COM(2016) 270 of 4 May 2016.

45 See Article 19(2) former Dublin II Regulation (EC) No 343/2003 [2003] OJ L50/1.

46 See ECJ, Ghezelbash, C-63/15, EU:C:2016:409, para 35; ECJ, A.S., C-490/16, EU:C:2017:585, paras 24-25; and ECJ, Mengesteab, C-670/16, EU:C:2017:587, paras 
case law can be expected to accept that choice. Article 13 ECHR does not prevent such restriction, since it applies only to those with an arguable claim that another human right was violated ${ }^{47}$-a condition the Commission carefully respects; it foresees a remedy for family links and regarding inhumane or degrading treatment. Article 47 CFR does not arguably require further protection either, since it should be read to presuppose, in cases not involving human rights, individual statutory rights, whose scope is determined by the legislature. ${ }^{48}$ Alternatively, interference may possibly be justified on proportionate public policy grounds. ${ }^{49}$

An Achilles heel of the reform proposal may be an exception for situations 'force majeure', which the Commission defines in rather general language in a non-binding recital: 'Member States may be faced with abnormal and unforeseeable circumstances outside their control, the consequences of which could not have been avoided in spite of the exercise of all due care. ${ }^{50}$ That is relevant for our topic, since invocation of force majeure would effectively suspend take back procedures. ${ }^{51}$ To be sure, take back procedures rarely result in the actual transfer anyway, but their official suspension might be a signal, in light of previous comments on the scant knowledge base, individuals might possibly read as an invitation to move elsewhere. Member States can activate the suspension clause unilaterally, without having asked the Commission or the Council for authorisation. In case the situation endures for more than one year, countries where asylum seekers are factually residing would officially have to assume responsibility and perform the asylum procedure. ${ }^{52}$

41-62; as well as Maarten den Heijer, 'Remedies in the Dublin Regulation: Ghezelbash and Karim' (2017) 54 CML Rev. 859, 862-869; contra ECJ, Abdullahi, C-394/12, EU:C:2013:813, para 60; and ECJ, Puid, C-4/11, EU:C:2013:740, paras 25-31 on the former Dublin II Regulation.

47 See ECtHR, judgment of 21 January 2011 [GC], No. 30696/09, M.S.S. v. Belgium \& Greece, para 288.

48 See Advocate General Michal Bobek, El Hassani, C-403/16, EU:C:2017:659, paras 74-84.

49 See Article 52(1) CFR; and the critical position of Siliva Morgades-Gil, 'The Right to Benefit from an Effective Remedy against Decisions Implying the Return of Asylum Seekers to European Safe Countries' (2017) 19 EJML 255, 274-277.

50 Recital 7 Proposal for a Crisis and Force Majeure Regulation, COM(2020) 613 of 23 September 2020.

51 Ibid, Article 8(3).

52 Ibid, Article 8(3) third sentence. 


\section{7. 'Sticks': Sanctioning Disrespect for EU Rules}

In line with the earlier observation that positive and negative sanctions can be combined, the Commission reiterates some of the sanctions which had featured in the 2016 Proposal for a Dublin IV Regulation. Those moving elsewhere will be subject to an accelerated asylum procedure; ${ }^{53} \mathrm{a}$ preclusion period for submitting relevant information shall be introduced, whose practical effects would depend on how domestic courts handle the provision; ${ }^{54}$ an additional, express obligation not to engage in secondary movements and to comply with transfer decisions cannot be expected to change much in practice. ${ }^{55}$ Secondary movements of asylum seekers are illegal already. The absence of border controls in the Schengen area should not be misunderstood as legal authority to cross internal borders. Doing so presupposes the possession of a residence permit, which asylum seekers do not have. ${ }^{56}$ Beneficiaries of international protection have a residence permit, but they may often lack sufficient resources, or cannot justify the purpose of a short-stay of no more than 90 days, followed by return to the country responsible. As a result, they are not covered by the provisions authorising intra-European mobility for short stays within the Schengen area. ${ }^{57}$ It may be appropriate to render these somewhat obscure provisions better known, but reaffirming that secondary movements are illegal will not change much in practice.

The most significant sanction is the reduction of social benefits in line with the ongoing negotiations on the reform of the Reception Conditions

53 See Article 40(1)(g) Proposal for an Asylum Procedures Regulation, $\operatorname{COM}(2016)$ 467 of 13 July 2016, read in conjunction with Article 9(1) Proposal for an AMMR Regulation (n 22).

54 Ibid Article 10(2); in Germany, for instance, administrative Courts are obliged to verify the fact ex officio; preclusion clauses for arguments put forward by the parties may not have much practical effects as a result.

55 Article 9(4)(a), (5) Proposal for an AMMR Regulation (n 22).

56 See Article 21(3) Convention Implementing the Schengen Agreement (adopted 19 June 1990, entered into force 1 September 1993) [2000] OJ L239/19, as amended by Regulation (EU) No 265/2010 as regards movement of persons with a long-stay visa [2010] OJ L85/1; and Article 9(1) Asylum Procedures Directive 2013/32/EU.

57 Ibid Article 21(3) read in conjunction with Article 6(1) Schengen Borders Code Regulation (EU) 2016/399; see also, on previous disputes between France and Italy on movement of those with domestic temporary protection, Sara Casella Colombeau, 'Crisis of Schengen? The Effect of Two "Migrant Crises" (2011 and 2015) on the Free Movement of People at an Internal Schengen Border' (2020) 46 Journal of Ethnic and Migration Studies 2258, 2264-2266. 
Directive. ${ }^{58}$ However, the Commission proposes to introduce a double caveat limiting the scope of the reduction ratione materiae. Note that the reduction remains subject to a threefold caveat. Firstly, it shall apply once a transfer decision has been notified to the individual; it would not take effect automatically whenever someone files a second asylum application. Secondly, the general scheme of the draft legislation indicates that the reduction will come to an end with the transfer of jurisdiction. It would not, therefore, result in permanent exclusion from social benefits. Thirdly, the Council's compromise text states that the reduction shall be 'without prejudice to the need to ensure a standard of living in accordance with [the Charter]', whose exact requirements remain uncertain at this juncture.

Notwithstanding these caveats, the effects of the reduction in social assistance should not be overestimated. While the level of benefits can influence secondary movements in line with previous comments, other factors are more relevant, notably the prospect of labour market success. These broader pull factors, in particular different degrees of economic attractiveness, cannot be influenced by secondary legislation. Social and economic discrepancies between different Member States will persist; CEAS legislation cannot establish a comprehensive level playing field.

Closer inspection shows that the degree of harmonisation remains limited, even in those subject areas where the legislature has regulatory leverage. The future Qualification Regulation aims to establish a 'uniform status' throughout the Union, but does so by obliging Member States to treat beneficiaries of international protection akin to nationals, thereby reiterating discrepancies between the level of domestic welfare payments. A refugee will receive less support in Bulgaria than in Belgium. ${ }^{59}$ During the asylum procedure, the situation is similar, since the Proposal for a Recast of the Reception Conditions Directive continues to guarantee an 'adequate standard of living', mirroring rules for nationals. ${ }^{60}$ Crucially, I do not claim that the Commission should instruct Member States to

58 See Article 17a Commission Proposal for a Recast of the Reception Conditions Directive, $\operatorname{COM}(2016) 465$ of 13 July 2016; and the provisional political compromise among the Member States enshrined in Council doc. 10009/18 of 18 June 2018.

59 Article 34 Commission Proposal for a Qualification Regulation, COM(2016) 466 of 13 July 2016 establishes benefits for nationals as a point of reference, although lower standards are permissible; similarly at present, Article 29 Qualification Directive 2011/95/EU.

60 Article 16(2), (6) Proposal for a Recast of the Reception Conditions Directive (n 58) are by and large identical with Article 17(2), (5) Reception Conditions Directive 2013/33/EU. 
give higher level of benefits to beneficiaries of international protection than to nationals. All I intend to say is that the Commission is in a regulatory dilemma when harmonising reception conditions during the asylum procedure and after recognition. Domestic asylum systems are bound to mirror the discrepancies in welfare levels between the 27 Member States of the European Union.

Somewhat surprisingly, the Commission presented another idea how to respond to irregular movements in December 2021, in the overall context of an amendment of the Schengen Borders Code. Doing so recognises that Schengen and Dublin have always been linked, politically at least. ${ }^{61}$ In order 'to counter irregular movements between Member States' 62 the Commission suggests introducing a novel mechanism for refusal of entry and the direct transfer to neighbouring countries. By way of example, Austria could cooperate with Slovenia to return people apprehended 'as part of cross-border police operational cooperation, in particular, during joint police patrols'63. This limitation effectively excludes unilateral returns without the consent of neighbouring states. Individuals would be returned there on the basis of a standard form within a short period of no more than one day; legal remedies are available but are foreseen not to have suspensive effect. ${ }^{64}$ Even though the instrument has apparently been designed to apply to refugees and asylum seekers, the proposal remains silent on how it relates to the asylum acquis. It remains unclear, in particular, whether the transfer could take place if the person applied for asylum. In that respect much will depend on the reform of the Dublin system. Beneficiaries of international protection, in particular, might be covered by the new instrument on rejection at internal borders, provided that EU institutions agree not to transfer asylum jurisdiction for those holding a protection status already.

61 Remember that on asylum jurisdiction in today's Dublin III Regulation reiterates the original compromise enshrined in Articles 28-38 Convention Implementing the Schengen Agreement (n 56); see Agnes Hurwitz, The Collective Responsibility of States to Protect Refugees (OUP 2009) 35.

62 Recital 25 Commission Proposal for an Amendment of the Schengen Borders Code Regulation (EU) 2016/399, COM(2021) 891 of 14 December 2021.

63 Ibid Article 23a(1)(c).

64 Ibid Article 23(a), read in conjunction with Annex XII. 


\section{Continuation of the Status Quo: Transfer of Jurisdiction}

A surprising novelty of the Pact on Migration and Asylum was the absence of 'stable', or even 'permanent', asylum jurisdiction. Instead, the Commission retains the individual right to a second asylum procedure, which effectively obliges Member States to officially assume jurisdiction and to assess the merits of an application once the transfer to the state responsible has failed in practice. ${ }^{65}$ In particular, the Commission proposes to maintain the six-month rule during which the transfer must take place, while abolishing the three-month time limit for the initiation of the take back notification, which is less relevant in practice. ${ }^{66}$ Moreover, the Commission considerably broadens the current extension of the time limit of six months for the actual transfer whenever asylum seekers 'abscond': in cases of absconding, the take back option endures indefinitely, instead of the current 18 -month deadline ${ }^{67}$ In practice, however, the practical impact of the extension would be limited, since the Court of Justice interprets the meaning of 'absconding' narrowly, excluding 'simple' scenarios of individuals obstructing transfers, for as long as authorities know where they reside. ${ }^{68}$

The transfer of jurisdiction effectively reiterates the legislative status quo under the Dublin III Regulation that allows for double (and threefold ${ }^{69}$ ) asylum applications in cases of secondary movements. That move is a departure from the Proposal of 2016, which had suggested perpetuating asylum jurisdiction: the failure of the take back procedure was no longer supposed to entail a transfer of responsibility. Asylum seekers were expected to return to the state responsible instead of receiving a second, albeit accelerated procedure elsewhere. This political about-turn is even more surprising if we remember that the European Parliament had supported the discontinuation of the transfer of jurisdiction, while the Council had called it a 'stable responsibility' for a period of five or eight years. ${ }^{70}$

65 See Articles 27(1), 35(1), (2) Proposal for an AMMR Regulation (n 22).

66 Article 21(1)(3) Dublin III Regulation (EU) No 604/2013 shall be discontinued.

67 Contrast Article 35(2)(2) Proposal for an AMMR Regulation (n 22) with Article 29(2) Dublin III Regulation (EU) No 604/2013.

68 See ECJ, Jawo, C-163/17, EU:C:2019:218, paras 52-65.

69 See ECJ, Hasan, C-360/16, EU:C:2018:35, paras 21-45, 71-88.

70 The EP LIBE Committee's Report (n 30) had sponsored far-reaching solidarity measures, including mandatory relocation, while supporting permanent jurisdiction; on deliberations within the Council, see Article 9a Presidency's compromise proposals (n 22). 
There is, however, one scenario in relation to which the Commission wants to introduce permanent jurisdiction: beneficiaries of international protection. To start with, beneficiaries of international protection will be covered by the take back obligation under the new Asylum and Migration Management Regulation, in contrast to the Dublin III Regulation. ${ }^{71}$ What is more, the Commission generally excluded beneficiaries of international protection from the transfer of jurisdiction enshrined in Article 27(1)(2) of the Proposal for an Asylum and Migration Management Regulation. The end result leaves us with a mixed overall message: transfer of jurisdiction would be abandoned for beneficiaries of international protection, not however for asylum seekers, as well as for those whose application was rejected or who have been granted complementary humanitarian protection under domestic laws. If these people moved on, they might still receive a second full asylum procedure in the country of their choice.

The question of permanence will undoubtedly feature prominently in the political negotiations. Several Member States have called for the abrogation of the transfer of jurisdiction, which the EP's Draft Report leaves intact. ${ }^{72}$ It seems to me that the continued availability of double asylum applications can be read as an implicit recognition, on the part of the Commission, that-notwithstanding the insistence on a 'fresh start' through a 'new' pact ${ }^{73}$ - the practical effects of the proposals would not differ decisively from the status quo. The solidarity mechanism remains feeble and the novel emphasis on return might not work in practice. Secondary movements would be here to stay, together with the first entry criterion.

\section{Conclusion: Overcoming the Vicious Circle}

For many years, the Commission had pursued a negotiation strategy based on alleged win-win scenarios: its proposals were presented to satisfy the needs and desires of (almost) everyone. The 'pact' follows the reverse scenario. Commissioner Johansson predicted: 'I will have zero Member States

71 Compare Article 26(1)(c) Proposal for an AMMR Regulation (n 22) with Article 18(1) Dublin III Regulation (EU) No 604/2013.

72 See Council docs 5755/21 of 29 January 2021; and 11617/21 of 9 July 2021; the EP's LIBE Committee Draft Report (n 23) does not propose to amend Articles 27(1), 35(2).

73 See Daniel Thym's introductory chapter to this volume. 
saying it's a perfect proposal. ${ }^{74}$ She was certainly correct, as indicated by the reaction of Southern states to the solidarity mechanism and of Northern countries to secondary movements. If the proposals were adopted as they stand, we might be confronted with more of the same, albeit under changed circumstances: a bit more solidarity and slightly less secondary movements, which, nonetheless, would result in a transfer of jurisdiction in many cases. That may not be the reset button some had hoped for, but it could be a realistic assessment of what might reasonably be achieved at this juncture. We shall see whether this lack of ambition is enough for Member States and the European Parliament to find common ground.

Would the situation be satisfactory in the medium run if the Commission proposals found their way into the Official Journal? I doubt that the cleavages between Member States would be overcome. 'Frontline' Member States would continue complaining about the absence of meaningful solidarity, while countries further North would decry the persistence of irregular movements. The two competing narratives that have haunted European asylum policy in recent years would be here to stay. We might even see a vicious circle of continued reciprocal accusations about the lack of solidarity and responsibility at the same time. Instead of mutual trust, reticence among Member States would be enhanced.

The end result might be convergence on the lowest common denominator: prevent refugees from entering Europe in the first place, by means of externalisation, to avoid poisonous debates about solidarity and secondary movements. For those who do not want such an outcome, the overall lesson stands out: overcome the false dichotomy between either more solidarity or less secondary movements, as well as between either positive incentives or negative sanctions. Try to optimise compliance by designing rules that might work reasonably well in practice. Such a reform would certainly not bring about a brave new world of European asylum law, but it may be a pragmatic move to prevent the Common European Asylum System from becoming dysfunctional by means of external closure in response to protracted compliance deficits and intergovernmental cleavages.

74 See Alexandra Brzozowski, 'EU's New Migration Pact to Request "Mandatory Solidarity" from Member States' (EurActiv.com, 23 September 2020) <www.eurac tiv.com/section/justice-home-affairs/news/eus-new-migration-pact-to-request-man datory-solidarity-from-member-states/> accessed 15 December 2021. 
